\title{
Peningkatan Hasil Bimbingan TIK Siswa melalui Penggunaan E-learning
}

Muttaqin Kholis Ali

Program Studi Pendidikan Teknologi dan Kejuruan, Fakultas Teknik, Universitas Negeri Padang, Indonesia

\section{Article Info}

\section{Article history:}

Received May $20^{\mathrm{h}}, 201 \mathrm{x}$

Revised Jun $15^{\text {th }}, 201 \mathrm{x}$

Accepted Jul 22 $2^{\text {th }}, 201 x$

\section{Keyword:}

E-Learning

Effectiveness

ICT

Learning achievement

\begin{abstract}
The purpose of this research is to determine the increase in ICT learning outcomes through the application of E-Learning in class X MIA 1 students at SMA Negeri 1 Tambangan. The research method used is quasi experimental with a pretest-posttest control group design. The research divides the control class using conventional learning media and the experimental class using ELearning media. The data analysis method is descriptive quantitative. The results obtained from this research is that the applied E-Learning can improve student's learning achievement. It is evident from the pretest and posttest mean scores which increased from 67.03 to 86.09 . The application of E-Learning is also more effective than the application of conventional learning, as evidenced by the normalized gain value of the experimental class of $\mathrm{g}=0.54$ is higher than the gain value of the control class of $g=0.30$. Besides, the results of the posttest hypothesis test with t-test showed $\mathrm{P}(0.006)<\propto(0.05)$ so that the research hypothesis is accepted. The conclusion obtained from this research is that the application of the E-Learning can improve the ICT learning achievement of class X MIA 1 SMA Negeri 1 Tambangan.
\end{abstract}

(C) 2021 The Authors. Published by IICET.

This is an open access article under the CC BY-NC-SA license

(https://creativecommons.org/licenses/by-nc-sa/4.0)

\section{Corresponding Author:}

Ali, M. K.,

Program Studi Pendidikan Teknologi dan Kejuruan, Fakultas Teknik, Universitas Negeri Padang, Indonesia

Email: muttaqinkholis51@gmail.com

\section{Pendahuluan}

Perkembangan Teknologi Informasi dan Komunikasi (TIK) telah membawa perubahan yang sangat besar bagi kemajuan dunia pendidikan. Seiring dengan perkembangan tersebut, metode pembelajaran juga banyak mengalami perkembangan, baik metode pembelajaran secara personal, media pembelajaran, ataupun proses pembelajaran. Pada pembahasan tentang media, istilah media pendidikan dan media pembelajaran pada beberapa literatur menunjukkan makna yang sama dan dapat digunakan secara bergantian. Gagne dalam Y. Miarso (2004) menyatakan bahwa media pendidikan adalah berbagai jenis komponen dalam lingkungan siswa yang dapat merangsang siswa untuk belajar. Sementara itu, media pembelajaran adalah segala sesuatu yang digunakan untuk menyalurkan pesan serta dapat merangsang pikiran, perasaan, perhatian, dan kemauan siswa sehingga dapat mendorong terjadinya proses belajar yang disengaja, bertujuan dan terkendali ${ }^{[1]}$. Media pembelajaran juga dapat meningkatkan proses belajar dan hasil belajar siswa ${ }^{[2]}$.

Bentuk dari perkembangan TIK yang diterapkan di dunia pendidikan adalah Electronic Learning (ELearning). E-Learning adalah segala pemanfaatan atau penggunaan teknologi internet dan web untuk menciptakan pengalaman belajar yang inovatif dan interaktif. Media pembelajaran ini menggunakan TIK untuk mentransformasikan proses pembelajaran antara pendidik dan peserta didik. E-Learning dapat 
dipandang sebagai suatu pendekatan yang inovatif untuk dijadikan sebuah desain media penyampaian yang baik, terpusat pada pengguna, interaktif, dan sebagai lingkungan belajar yang memiliki berbagai kemudahankemudahan bagi siapa saja, di mana saja, dan kapan saja ${ }^{[3]}$. Pendapat lain menyatakan E-Learning adalah penggunaan teknologi informasi dan komunikasi sebagai alat; dengan tujuan meningkatkan efisiensi, efektivitas, transparansi, akuntabilitas, dan kenyamanan belajar; dengan obyeknya adalah layanan pembelajaran yang lebih baik, menarik, interaktif, dan atraktif ${ }^{[4]}$. Hasil akhir yang diharapkan adalah peningkatan prestasi dan kecakapan akademik peserta didik serta pengurangan biaya, waktu, dan tenaga dalam pelaksanaan proses pembelajaran.

Dalam pembelajaran di kelas, E-Learning memiliki tiga fungsi yaitu: (1) Suplemen (tambahan), apabila siswa memiliki kebebasan memilih menggunakan materi pembelajaran elektronik atau tidak; (2) Komplemen (pelengkap), apabila materi pembelajaran elektronik digunakan untuk melengkapi materi pembelajaran yang diterima siswa di kelas; (3) Substitusi (pengganti), apabila E-Learning dilakukan sebagai pengganti kegiatan belajar ${ }^{[5]}$.

E-Learning merupakan salah satu bentuk alat pendukung Student Centered Learning (SCL). SCL adalah metode pembelajaran yang memungkinkan guru dan penyelenggara pendidikan memberikan otonomi dan kendali lebih besar kepada siswa untuk menentukan materi pelajaran, model pembelajaran, dan cepat-lambat tahapan dalam pembelajaran ${ }^{[6]}$. Pembelajaran dengan $S C L$ mendorong siswa menentukan tujuan yang dapat dicapai, menilai hasil belajarnya sendiri, membantu bekerja sama dalam kelompok, dan memastikan agar mereka mengetahui bagaimana memanfaatkan semua sumber belajar yang tersedia. Ciri khas $S C L$ ini sejalan dengan media pembelajaran E-Learning yang menuntut kemandirian dan keaktifan siswa dalam proses pembelajaran. Media pembelajaran E-Learning menyebabkan proses belajar tidak lagi hanya mendengarkan uraian materi dari guru, tetapi siswa juga melakukan aktivitas lain seperti mengamati, melakukan, mendemonstrasikan, dan lain-lain. Materi bahan ajar dapat divisualisasikan dalam berbagai format dan bentuk yang lebih dinamis dan interaktif sehingga learner atau murid akan termotivasi untuk terlibat lebih jauh dalam proses pembelajaran tersebut.

Pembelajaran konvensional dan pembelajaran E-Learning sendiri memiliki beberapa perbedaan krusial yaitu, (1) Pada pembelajaran konvensional, guru memainkan peran utama dalam memotivasi dan membimbing siswa sementara pada pembelajaran E-Learning, pembelajaran bergantung pada motivasi diri siswa; (2) Pada pembelajaran konvensional, tes dan ujian dilakukan sesuai jadwal yang telah ditentukan secara umum sedangkan pada pembelajaran E-Learning, tes dan ujian dilakukan sesuai dengan kecepatan daya tangkap siswa (3) Pada pembelajaran konvensional, laboratorium digunakan untuk eksperimen praktek sedangkan pada pembelajaran E-Learning, eksperimen praktek dilakukan melalui metode inovatif; (4) Pembelajaran konvensional memiliki kalender dan durasi yang tetap bagi tiap mata pelajaran dan ditentukan oleh institusi sedangkan pembelajaran E-Learning menyerahkan durasi mata pelajaran pada siswa, 5). Pada pembelajaran konvensional, kegiatan belajar dibatasi pada siswa yang bersekolah di institusi tersebut sedangkan pembelajaran E-Learning lebih sukses dalam jumlah pelajar yang mengikuti pembelajaran daring ${ }^{[7]}$.

SMA Negeri 1 Tambangan masih menerapkan pembelajaran konvensional. Pembelajaran konvensional yang dimaksud adalah pembelajaran yang penyampaian materinya diuraikan oleh guru dengan media pembelajaran standar, misalnya powerpoint atau tanpa media pembelajaran. Kemudian, guru memberikan soal (penugasan) kepada siswa dengan materi yang terbatas. Berdasarkan data yang diperoleh, secara umum siswa kelas X MIA 1 di SMA Negeri 1 Tambangan menunjukkan rendahnya ketertarikan dan minat dalam mengikuti pembelajaran TIK menggunakan metode konvensional. Masalah ini kemudian menyebabkan rendahnya hasil belajar siswa. Hasil belajar adalah tingkat penguasaan individu terhadap materi pembelajaran sebagai akibat dari perubahan perilaku setelah mengikuti proses belajar mengajar berdasarkan tujuan pengajaran yang ingin dicapai. Memperhatikan hal tersebut, kemungkinan sistem yang digunakan dalam pembelajaran kurang tepat sehingga berpengaruh pada hasil belajar yang belum maksimal.

Di sisi lain, sarana dan prasarana yang dimiliki sekolah seperti jaringan internet kurang dioptimalkan. Sekolah sudah memiliki E-Learning, namun belum dimanfaatkan secara optimal oleh guru mata pelajaran, terutama TIK. Selama ini, pencarian sumber belajar masih berkutat kepada informasi dari guru dan buku teks. Padahal, siswa membutuhkan akses belajar yang luas, aktif, kreatif, dan suasana belajar yang menantang. Mengingat pembelajaran adalah kegiatan yang bertujuan membelajarkan siswa ${ }^{[8]}$, maka guru sebagai fasilitator harus melakukan peningkatan kualitas pembelajaran yang bisa dicapai dengan mempertimbangkan beberapa perubahan-perubahan dalam proses pembelajaran. Beberapa perubahan tersebut misalnya perubahan dari model belajar terpusat pada guru ke model terpusat pada peserta didik, dari kerja terisolasi ke kerja kolaborasi, dari pengiriman informasi sepihak ke pertukaran informasi, dari pembelajaran pasif ke pembelajaran aktif dan partisipatif, dari yang bersifat faktual ke cara berpikir kritis, dari respon reaktif ke proaktif, dari konteks artificial ke konteks dunia nyata, dari single media ke multimedia. 
Salah satu langkah perubahan yang dapat diambil untuk meningkatkan hasil belajar siswa pada mata pelajaran TIK pada kelas X MIA 1 di SMA Negeri 1 Tambangan adalah menerapkan media pembelajaran $E$ Learning. Dengan adanya media pembelajaran E-Learning, diharapkan proses pembelajaran menjadi lebih kondusif, meningkatkan minat siswa, meningkatkan proses belajar siswa dalam pembelajaran, dan meningkatkan hasil belajar siswa. Hal ini dikarenakan E-Learning menuntut siswa untuk bisa berinteraksi dengan internet, seperti mengakses informasi yang luas, memunculkan keaktifan siswa yang disebabkan tantangan, serta ketersediaan materi untuk pembelajaran.

Penelitian ini bertujuan untuk mengkaji pemanfaatan media pembelajaran E-Learning yang telah ada di SMA Negeri 1 Tambangan untuk mata pelajaran TIK pada kelas X MIA 1. Media pembelajaran E-Learning diharapkan dapat menjadi sumber belajar yang optimal untuk meningkatkan partisipasi dan hasil belajar siswa serta memaksimalkan peran guru sebagai fasilitator.

Penelitian mengenai penggunaan media pembelajaran E-Learning untuk meningkatkan hasil belajar siswa pernah dilakukan sebelumnya. Salah satu contohnya yaitu penelitian yang dilakukan oleh Kurnia Shinta Dewi pada tahun 2011 dengan judul Efektivitas E-Learning sebagai Media Pembelajaran Mata Pelajaran TIK Kelas XI di $S M A$ Negeri 1 Depok. Penelitian tersebut menunjukkan bahwa terdapat perbedaan prestasi mata pelajaran TIK di SMA Negeri 1 Depok yang diajarkan tanpa E-Learning dengan yang diajarkan menggunakan E-Learning ${ }^{[9]}$. Selain itu, ada juga penelitian dari Tegar Pambuditama pada tahun 2010 dengan judul Pengembangan Media Pembelajaran Berbasis E-Learning Untuk Meningkatkan Minat Siswa Terhadap Matematika (Pokok Bahasan Bangun Ruang SMA Kelas X Semester II) ${ }^{[10]}$. Penelitian ini menggunakan aplikasi blog pada pokok bahasan Bangun Ruang kelas X SMA.

Melihat beberapa penelitian sebelumnya, penelitian ini diharapkan dapat membawa manfaat yang sama yaitu untuk memberi sumbangsih pada ilmu pengetahuan tentang pengaruh penggunaan aplikasi E-Learning terhadap hasil bimbingan TIK siswa di kelas X MIA 1 SMA Negeri 1 Tambangan. Tak hanya itu, sekolah diharapkan dapat menyediakan teknologi E-Learning yang memiliki daya guna sehingga guru dapat termotivasi untuk menggunakan E-Learning dalam pembelajaran dan siswa dapat belajar secara lebih optimal.

\section{Metode}

Penelitian ini dilaksanakan di SMA Negeri 1 Tambangan yang berlokasi di Jalan Trans Sumatera BukittinggiPadang Sidempuan, Laru Lombang, Tambangan, Kabupaten Mandailing Natal, Sumatera Utara. Waktu penelitian ini dilaksanakan pada 16 Oktober 2020 sampai dengan 5 November 2020. Penelitian ini adalah penelitian quasi experimental yang menggunakan seluruh subjek dalam kelompok belajar (intact group) untuk diberi perlakuan (treatment), suatu produk atau instrumen penelitian ${ }^{[11]}$. Lebih lanjut, penelitian ini menggunakan desain Pretest-Posttest Control Group Design. Kelompok eksperimen diberikan perlakuan penggunaan media pembelajaran E-Learning dan pada kelompok kontrol diberikan perlakuan konvensional yang diberlakukan di sekolah (media ceramah oleh guru). Adapun variabel penelitian ada dua yaitu variabel bebas tentang media pembelajaran E-Learning dan konvensional, serta variabel terikat yaitu hasil belajar. Variabel dapat didefinisikan sebagai berikut: (1) media pembelajaran E-Learning; (2) media pembelajaran konvensional; dan (3) hasil belajar siswa yang memiliki tujuan untuk mengetahui tingkat keberhasilan yang dicapai oleh siswa setelah mengikuti kegiatan pembelajaran.

Rancangan penentuan sampel pada penelitian ini menggunakan teknik Random Sampling, dimana sampelnya adalah siswa SMA Negeri 1 Tambangan kelas X MIA 1. E-Learning digunakan dalam mata pelajaran Teknologi Informasi dan Komunikasi dengan materi perangkat lunak pembuat presentasi. Kelas X MIA 1 diambil sebagai sampel sebab secara psikologis mereka masih dalam tahap adaptasi dengan teknologi pembelajaran tingkat SMA. Untuk mengetahui keadaan lapangan dan menguatkan dalam pengambilan keputusan, observasi dilakukan dengan mengikuti pembelajaran di kelas dalam kondisi biasa (konvensional).

Metode yang digunakan untuk menganalisis data hasil penelitian ini adalah metode kuantitatif deskriptif. Pengolahan data secara kuantitatif ini mengolah data hasil pretest dan posttest. Pengolahan data meliputi pemberian skor berdasarkan metode Right Only dan analisis data skor hasil pretest dan posttest. Penelitian yang menggunakan Pretest-Posttest Control Group Design ini memiliki alur sebagai berikut: Pertama, identifikasi masalah dan tujuan penelitian dilanjutkan yang kedua yaitu melakukan studi literature. Ketiga, pembuatan instrumen dan bahan ajar yang meliputi pembuatan materi untuk E-Learning dan pembuatan butir soal. Instrumen penelitian adalah suatu alat yang digunakan untuk mengukur fenomena alam maupun sosial yang diamati ${ }^{[12]}$. Untuk melihat hasil belajar siswa dalam pembelajaran TIK menggunakan E-Learning, instrumen yang digunakan adalah soal tes pilihan ganda yang disusun berdasarkan silabus kelas $\mathrm{X}$ semester 2 mata pelajaran TIK mengenai perangkat lunak pembuat presentasi. Macam tes dibuat dari yang mudah ke yang sulit 
untuk dapat menerapkan pemahaman yang runtut. Tipe soal tes meliputi klasifikasi pemahaman, hafalan, dan penerapan. Usai membuat instrumen penelitian, langkah selanjutnya adalah pengujian. Uji yang dilakukan yaitu validitas instrumen, reliabilitas instrumen, tingkat kesukaran, dan daya pembeda.

Keempat, membagi unit percobaan menjadi dua kelompok. Kelompok pertama menggunakan metode $E$ Learning web sebagai kelompok eksperimen dan kelompok kedua menggunakan media pembelajaran konvensional sebagai kelompok kontrol. Kelima, memberikan pretest kepada kelompok eksperimen dan kelompok kontrol. Pretest digunakan untuk mengukur kemampuan awal kedua kelompok. Soal tes yang diberikan harus sama dan telah melalui proses uji coba instrumen. Hasil pretest dari tiap kelompok kemudian dihitung mean-nya. Keenam, memberikan perlakuan (treatment) yang berbeda kepada kedua kelompok. Kelompok eksperimen diberikan perlakuan dengan menggunakan media pembelajaran E-Learning dan kelompok kontrol diberikan perlakuan pembelajaran konvensional.

Perlakuan dengan media pembelajaran E-Learning dilakukan melalui tahap constructivisme, cooperative learning, E-Learning, referensi individu, dan budaya belajar. Tahap constructivisme meliputi pengulangan materi sebelumnya, memotivasi siswa untuk mempelajari manfaat materi yang akan dipelajari, dan membangun pemahaman materi sejak awal. Tahap cooperative learning yaitu membuka dan log in E-Learning, mempelajari labsheet dan referensi, serta mengerjakan tugas praktek. Setelah itu, pembelajaran E-Learning yang sesuai dengan materi pembelajaran dilangsungkan. Guru sebagai fasilitator mengoptimalkan penggunaan internet dalam pembelajaran agar siswa dapat memperoleh budaya belajar mandiri ${ }^{[13]}$. Sementara itu, media pembelajaran konvensional melalui tahap pembukaan, pembelajaran, dan penutup. Tahap pembukaan meliputi review materi sebelumnya, mengisi daftar kehadiran, dan menilai tugas sebelumnya. Tahap pembelajaran yaitu guru mendemonstrasikan materi, siswa mengerjakan tugas, dan penilaian tugas praktek. Pada tahap terakhir yaitu penutup, guru menyampaikan tugas pekan depan.

Ketujuh, memberikan posttest kepada kelompok eksperimen dan kelompok kontrol. Sama seperti pretest, soal posttest juga harus setara untuk kedua kelompok sehingga uji coba cukup dilakukan sekali untuk mengukur validitas dan reabilitas instrumen tes. Posttest dilakukan untuk melihat perbedaan hasil tes yang terjadi antara kelas kontrol dan kelas eksperimen di mana yang satu diberi perlakuan dan yang lainnya tidak. Hasil posttest dari tiap kelompok juga dihitung mean-nya.

Kedelapan, mengolah dan menganalisis data skor hasil pretest dan posttest. Nilai pretest dan posttest yang telah diperoleh kemudian diolah melalui enam langkah. Langkah pertama adalah menghitung nilai rata-rata kelompok, minimum maksimum, standar deviasi, dan varians menggunakan program SPSS 16.0. Langkah kedua adalah melakukan uji normalitas untuk mengetahui apakah data dari masing-masing kelompok sampel berdistribusi normal atau tidak. Pengujian normalitas sebaran data dilakukan dengan cara membandingkan nilai Kolmogorov-Smirnov dan probabilitas dengan nilai signifikansinya adalah 5\%. Langkah ketiga adalah melakukan uji homogenitas untuk mengetahui apakah data dari masing-masing kelompok sampel mempunyai varians yang sama atau berbeda. Untuk menguji homogenitas digunakan uji Levene dengan taraf signifikansi 5\%. Langkah keempat adalah melakukan uji kesamaan dua rata-rata untuk mengetahui apakah terdapat kesamaan antara rata-rata nilai pretest perolehan dari kelas kontrol dan kelas eksperimen sebelum dilakukan pembelajaran. Uji ini dilakukan jika data berdistribusi normal dan homogen, maka dilakukan uji $\mathrm{T}$ dengan taraf signifikansi 5\%. Langkah kelima adalah menghitung nilai gain ternormalisasi dengan melakukan selisih antara nilai posttest dan pretest. Nilai gain berguna untuk menunjukkan peningkatan pemahaman atau penguasaan konsep siswa setelah proses pembelajaran ${ }^{[14]}$. Langkah keenam adalah menguji hipotesis dan hasilnya akan digunakan sebagai acuan penarikan kesimpulan. Kesembilan, membahas hasil penelitian. Lalu yang terakhir, menarik kesimpulan.

\section{Hasil dan Analisis}

Penelitian ini menggunakan kelas eksperimen dan kelas kontrol sebagai pembanding. Kelas eksperimen (XA) dengan jumlah siswa 32 orang belajar menggunakan media pembelajaran E-Learning sementara kelas kontrol (XB) dengan jumlah siswa 29 orang belajar menggunakan media pembelajaran konvensional. Penelitian terhadap sampel dilakukan selama masing-masing empat kali pertemuan untuk 2 kompetensi dasar animasi transisi sederhana dan hyperlink pada presentasi Power Point 2007. Jumlah pertemuan yang dilakukan disesuaikan dengan standar kompetensi dan kompetensi dasar yang harus dicapai siswa.

Data pokok yang diperoleh dalam penelitian ini adalah data nilai hasil belajar siswa dalam mata pelajaran Teknologi Informasi dan Komunikasi (TIK) dengan menggunakan instrumen penelitian yang telah divalidasi. Sebelum melakukan pengujian hipotesis penelitian, terlebih dahulu akan dianalisis mengenai nilai rata-rata siswa, normalitas dan homogenitas yang diperoleh baik pada kelas eksperimen maupun pada kelas kontrol. 
Hasil pretest dan posttest pada kelas eksperimen menunjukkan bahwa perolehan nilai rata-rata hasil belajar siswa yaitu sebesar 67.03 dan 86.09. Sedangkan, pada kelas kontrol diketahui rata-rata skor pretest dan posttest adalah sebesar 67.31 dan 80.34. Dari data tersebut, dapat dilihat bahwa terdapat peningkatan hasil belajar siswa pada kelas eksperimen dan kontrol.

Analisis terhadap pretest dilakukan dengan tujuan mengukur kemampuan siswa sebelum menerima proses pembelajaran atau dengan kata lain mengukur kemampuan awal yang dimiliki siswa terkait dengan materi yang akan diajarkan. Berikut disajikan analisis statistik deskriptif skor pretest kelas eksperimen dan kelas kontrol dengan perhitungan menggunakan program SPSS 16.0.

Table $1<$ Tabel Statistik Deskriptif Hasil Pretest>

\begin{tabular}{llccc}
\hline Kelas & $\mathbf{N}$ & Mean & Min & Max \\
Eksperimen & 32 & 67.03 & 47 & 79 \\
Kontrol & 29 & 67.31 & 32 & 89 \\
\hline
\end{tabular}

Berdasarkan data pada tabel di atas, terlihat bahwa rata-rata skor pretest kelas eksperimen adalah 67.03 dengan skor maksimum 79 dan skor minimum 47. Sedangkan rata-rata skor pretest kelas kontrol adalah 67.31 dengan skor maksimum 89 dan skor minimum 32. Dapat dilihat juga bahwa rata-rata skor pretest kelas eksperimen dan kelas kontrol perbedaannya tidak terlalu jauh. Akan tetapi, untuk melihat apakah perbedaan tersebut cukup berarti atau tidak maka akan dilakukan uji statistik berupa uji normalitas, uji homogenitas, dan uji t.

Berdasarkan perhitungan uji normalitas maka pada kelas eksperimen diperoleh $\mathrm{P}=0.463$ dan pada kelas kontrol diperoleh $\mathrm{P}=0.332$. Dengan membandingkan nilai $\propto=0.05$, maka untuk kelas eksperimen $\mathrm{P}(0.463)$ $>\propto(0.05)$ dan kelas kontrol $\mathrm{P}(0.332)>\propto(0.05)$. Karena kedua $\mathrm{P}>\propto(0.05)$, dapat disimpulkan bahwa untuk kedua data tersebut berdistribusi normal. Setelah diketahui bahwa data pretest berdistribusi normal, maka langkah selanjutnya adalah melakukan uji homogenitas untuk mengetahui kesamaan varians antara skor pretest. Uji homogenitas pada pretest antara kelas eksperimen dan kelas kontrol menunjukkan $\mathrm{P}=0.075$. Dengan membandingkan nilai $\propto=0.05$, karena nilai untuk $\mathrm{P}(0.075)>\propto(0.05)$, maka dapat disimpulkan bahwa data tersebut berasal dari populasi dengan varians yang sama (homogen).

Sebelum penelitian dilakukan, kemampuan awal siswa kelas kontrol dan kelas eksperimen adalah sama (homogen). Hal ini dapat dilihat dari nilai rata-rata hasil pretest kedua kelas yang serupa dan dibuktikan dengan uji $t$ untuk melihat persamaan dua rata-rata. Dengan taraf signifikansi $5 \%$, hasilnya diperoleh $\mathrm{P}=$ 0.924 dan $_{h}=-0.096$. Dengan membandingkan nilai $\mathrm{P}(0.924)>\propto(0.05)$ dan ${ }_{h}<$, maka dapat diambil kesimpulan bahwa tidak ada perbedaan kemampuan awal antara kelas eksperimen dan kontrol. Hal ini wajar karena kedua kelas tersebut belum mendapatkan perlakuan dan materi belajar.

Usai memberi perlakuan kepada siswa, soal posttest diberikan di akhir rangkaian pembelajaran. Soal ini diberikan terakhir untuk mengetahui pengetahuan siswa setelah mengikuti proses pembelajaran yang diberi perlakuan berupa penerapan media pembelajaran E-Learning pada kelas eksperimen dan media pembelajaran konvensional pada kelas kontrol.

Tabel 2 <Tabel Statistik Deskriptif Hasil Posttest>

\begin{tabular}{lcccc}
\hline Kelas & N & Mean & Min & Max \\
Eksperimen & 32 & 86.09 & 74 & 100 \\
Kontrol & 29 & 80.34 & 63 & 100 \\
\hline
\end{tabular}

Berdasarkan tabel di atas terlihat bahwa skor tertinggi posttest kelas eksperimen adalah 100, skor terendahnya adalah 74, dan skor rata-rata kelas adalah 86.09 dengan standar deviasi sebesar 7.92448. Sedangkan skor tertinggi posttest kelas kontrol adalah 100 dan terendahnya adalah 63. Skor rata-rata kelas adalah 80.34 dengan standar deviasi sebesar 8.66551. Dari data di atas, dapat dilihat bahwa rata-rata skor posttest kelas eksperimen dan kelas kontrol perbedaannya agak jauh. Dari nilai rata-rata posttest terlihat bahwa hasil belajar kelas eksperimen lebih tinggi dibandingkan kelas kontrol. Akan tetapi, untuk melihat apakah perbedaan tersebut cukup berarti atau tidak maka akan dilakukan uji statistik.

Berdasarkan perhitungan uji normalitas maka pada kelas eksperimen diperoleh $\mathrm{P}=0.398$ dan kelas kontrol diperoleh $\mathrm{P}=0.724$. Jika membandingkannya dengan nilai $\propto=0.05$, maka diperoleh hasil untuk kelas eksperimen $\mathrm{P}(0.398)>\propto(0.05)$ dan untuk kelas kontrol $\mathrm{P}(0.724)>\propto(0.05)$. Sehingga, dapat disimpulkan bahwa kedua data tersebut berdistribusi normal. Setelah itu, berdasarkan perhitungan uji homogenitas, nilai $\mathrm{P}$ posttest antara kelas eksperimen dan kelas kontrol diperoleh $\mathrm{P}=0.744$. Jika menbandingkannya dengan nilai $\propto$ 
$=0.05$, diperoleh $\mathrm{P}(0.744)>\propto(0.05)$. Sehingga, dapat disimpulkan bahwa data tersebut berasal dari populasi dengan varians yang sama.

Setelah dilakukan uji normalitas dan uji homogenitas data dari hasil posttest diketahui bahwa penyebaran skor posttest kelas eksperimen dan kontrol berdistribusi normal sehingga untuk menguji perbedaan dua ratarata posttest digunakan uji statistik parametrik uji $t$. Uji $\mathrm{t}$ dilakukan untuk menguji hipotesis efektivitas penggunaan media pembelajaran E-Learning berbasis web lebih tinggi dari penggunaan media pembelajaran konvensional dalam meningkatkan hasil belajar siswa kelas X MIA 1 di SMA Negeri 1 Tambangan pada pelajaran Teknologi Informasi dan Komunikasi. Berdasarkan hasil uji t, diperoleh hasil bahwa signifikansi (P) adalah 0.006. Karena signifikansi $\mathrm{P}(0.006)<\propto(0.05)$, hipotesis diterima. Artinya dapat disimpulkan bahwa efektivitas pembelajaran TIK menggunakan media pembelajaran E-Learning lebih tinggi daripada menggunakan media pembelajaran konvensional.

Untuk mengetahui keefektifan penggunaan media pembelajaran E-Learning berbasis web pada kelas eksperimen dan penggunaan media pembelajaran konvensional juga digunakan perhitungan nilai gain. Skor gain diperoleh dari selisih antara skor pretest dan skor posttest baik siswa yang belajar dengan menggunakan media pembelajaran E-Learning maupun siswa yang belajar menggunakan media pembelajaran konvensional. Karena hasil belajar merupakan hasil yang diperoleh siswa setelah pembelajaran, maka hasil belajar yang dimaksud yaitu adanya peningkatan yang dialami siswa. Untuk mengetahui efektivitas penggunaan media pembelajaran E-Learning pada kelas eksperimen dan penggunaan media pembelajaran konvensional pada kelas kontrol digunakan perhitungan gain ternormalisasi. Hasil perhitungan tes dengan menggunakan gain ternormalisasi diperoleh nilai $g$ untuk kelas kontrol adalah sebesar 0.30 sedangkan nilai $g$ untuk kelas eksperimen adalah sebesar 0.54 . Nilai tersebut diinterpretasikan ke dalam kriterium nilai $\langle g\rangle$, diperoleh efektivitas media pembelajaran E-Learning di kelas eksperimen tergolong sedang. Jika dibandingkan nilai gain antara kelas eksperimen dengan kelas kontrol, dapat disimpulkan bahwa efektivitas penggunaan media pembelajaran E-Learning di kelas eksperimen lebih tinggi daripada kelas kontrol yang menggunakan media pembelajaran konvensional. Nilai rata-rata pretest, posttest, dan nilai gain jika digambarkan dalam bentuk tabel sebagai berikut.

Tabel $3<$ Nilai Rerata Pretest, Posttest, Serta Nilai Gain Kelas Eksperimen dan Kontrol>

\begin{tabular}{lccccc}
\hline Kelas & $\begin{array}{c}\text { Rata-rata } \\
\text { Pretest }\end{array}$ & $\begin{array}{c}\text { Rata-rata } \\
\text { Posttest }\end{array}$ & Gain & $\begin{array}{c}\text { Gain } \\
\text { ternormalisasi } \\
<\boldsymbol{g}>\end{array}$ & Kriteria \\
Eksperimen & 67.03 & 86.09 & 19.06 & 0.54 & Sedang \\
Kontrol & 67.31 & 80.34 & 13.03 & 0.30 & Sedang \\
\hline
\end{tabular}

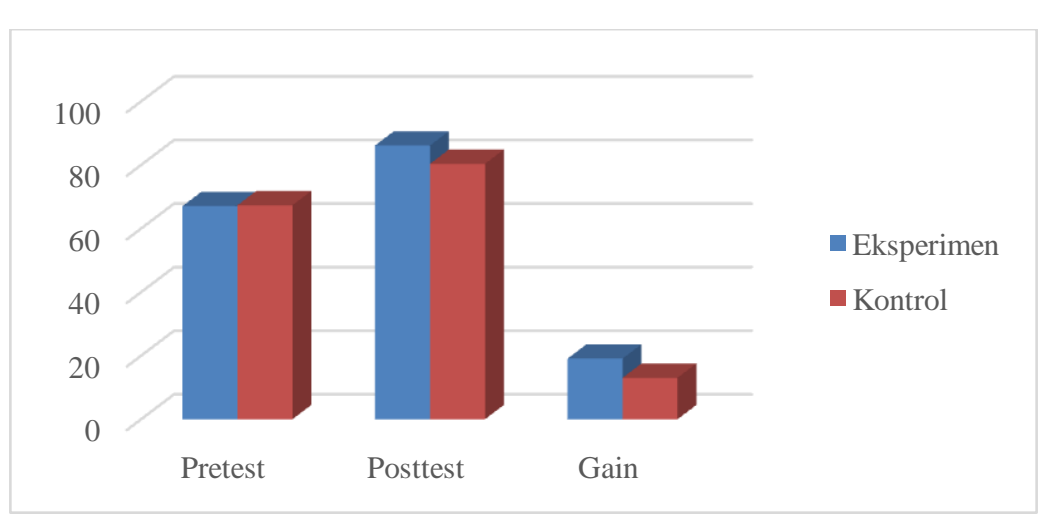

Grafik $1<$ Nilai Rerata Pretest, Posttest, dan Nilai Gain Kelas Eksperimen dan Kontrol>

Berdasarkan hasil penelitian yang dilakukan, di kelas eksperimen siswa dituntut untuk dapat berperan lebih aktif dalam memperoleh kesempatan membangun sendiri pengetahuannya sehingga mereka dapat memperoleh pemahaman yang mendalam. Pada media pembelajaran E-Learning, siswa dapat mencari dan mengambil informasi atau materi pembelajaran dari internet secara mandiri. Siswa akan memiliki kekayaan informasi, sebab ia dapat mengakses informasi yang berhubungan dengan materi pembelajarannya dari mana saja dan kapan saja. Bahkan, siswa juga dapat berdiskusi secara online dengan pakar-pakar pada bidangnya, melalui e-mail atau chatting. Dengan demikian, jelas bahwa keaktifan peserta didik dalam E-Learning sangat 
menentukan hasil belajar yang mereka peroleh. Semakin siswa aktif mencari informasi, semakin banyak pula pengetahuan atau kecakapan yang diperoleh.

Terdapat alasan psikologis keaktifan siswa dalam pembelajaran dapat meningkatkan hasil belajar. Siswa SMA yang sedang masuk pada tahap perkembangan orang dewasa umumnya sudah mampu berpikir secara ilmiah, memecahkan persoalan dengan logika, dan memecahkan masalah verbal yang kompleks karena sudah mencapai kematangan struktur kognitif. Menyikapi hal ini, guru bisa mengalihkan dominasi pembelajaran kepada siswa. Seorang guru yang baik harus berupaya untuk banyak mendengarkan dan menerima gagasan, kemudian menilai dan menjawab pertanyaan yang diajukan. Anak SMA yang akan beralih menjadi orang dewasa dapat belajar lebih aktif apabila mereka merasa ikut dilibatkan dalam aktivitas pembelajaran, terutama jika mereka diberikan kesempatan untuk memberi sumbangan pikiran dan gagasan. Kesempatan tersebut akan membuat siswa merasa berharga dan memiliki harga diri di depan sesama temannya ${ }^{[15]}$. Maka, siswa pun dapat meningkatkan pemahaman dan hasil belajar.

Media pembelajaran E-Learning juga memungkinkan siswa menjalani proses pembelajaran yang lebih bervariasi. Sebab, bahan pembelajaran E-Learning yang dirancang dengan baik dan profesional akan memperhatikan dan menggunakan ciri-ciri multimedia. Artinya, dalam bahan pembelajaran tersebut di samping memuat teks, juga dapat memuat gambar, grafik, animasi, simulasi, audio, dan video. Pemilihan warna yang baik dan tepat juga akan meningkatkan penampilan di layar monitor. Selain itu, siswa juga dapat meng-upload, men-download maupun mendemonstrasikan hasil praktik belajarnya. Hal ini menjadikan bahan pembelajaran E-Learning menjadi lebih menarik, berkesan, interaktif dan atraktif. Keadaan semacam ini memungkinkan peserta didik selalu ingat tentang materi pelajaran yang dipelajari.

Peningkatan hasil belajar yang diraih oleh kelas eksperimen dikarenakan adanya suasana belajar di kelas yang lebih kondusif, aktif dan minat serta antusias siswa sangat terlihat dibandingkan pada kelas kontrol, terutama dalam distribusi materi pembelajaran yang tidak terpusat hanya pada guru. Budaya belajar yang dikembangkan di kelas eksperimen adalah keaktifan siswa dalam membangun sendiri keingintahuannya, membangun karakter keinginan membantu teman yang kesulitan, serta pemanfaatan waktu yang optimal di kelas karena kegiatan sudah terstruktur dan terjadwal. Pada E-Learning terdapat kegiatan terstruktur untuk setiap pertemuan, sehingga siswa mampu memanajemen waktu belajar di kelas yang harapannya sejalan dengan mengoptimalkan fasilitas yang ada. Kegiatan pembelajaran yang terstruktur memungkinkan guru dan siswa saling menilai sampai berapa jauh bahan ajar dipelajari ${ }^{[16]}$. Dengan demikian, keaktifan siswa dalam membangun sendiri pengetahuannya diharapkan dapat membantu siswa untuk lebih lama mengingat dan memahami materi pelajaran.

Di samping hasil belajar siswa yang meningkat, kelebihan-kelebihan lain yang mendukung E-Learning efektif ditunjukkan dari beberapa indikator dalam proses pembelajaran, antara lain meningkatnya keaktifan siswa, baik dalam hal bertanya maupun mempresentasikan tugas yang telah diselesaikannya. Kelebihan lainnya adalah tugas siswa menjadi lebih variatif dan kreatif karena siswa memiliki sumber belajar yang luas sehingga memiliki referensi materi lebih banyak dibandingkan dengan siswa pada kelas kontrol yang tidak menggunakan media E-Learning. Keunggulan siswa yang menggunakan E-Learning adalah memiliki kemampuan lebih dalam berinteraksi dengan internet dan penggunaannya, misal paham tentang cara mengupload tugas serta mengetahui link-link belajar untuk meningkatkan kreativitas dalam mengerjakan tugas.

Pelaksanaan pembelajaran pada kelompok eksperimen pada awalnya mengalami sedikit hambatan. Pembelajaran yang baru bagi guru dan siswa memerlukan waktu untuk penyesuaian. Namun, hambatanhambatan yang terjadi perlahan dapat dikurangi karena partisipasi aktif siswa dalam proses pembelajaran. Aktivitas di dalam kelas yang bervariasi dapat menambah semangat, motivasi, karakter berbagi, membantu dalam memecahkan masalah dan dapat menciptakan lingkungan belajar positif, sehingga pembelajaran menjadi lebih interaktif dan efektif.

Hasil penelitian ini sejalan dengan hasil penelitian yang dilakukan oleh Kurnia Shinta Dewi (2011) dengan judul Efektivitas E-Learning Sebagai Media Pembelajaran Mata Pelajaran TIK Kelas XI di SMA Negeri 1 Depok. Penelitian yang menggunakan metode quasi experimental dengan kelas eksperimen dan kelas kontrol tersebut menunjukkan bahwa media pembelajaran E-Learning dapat meningkatkan prestasi belajar TIK. Dengan demikian, seluruh uraian di atas menunjukkan bahwa secara umum pembelajaran TIK dengan menggunakan media pembelajaran E-Learning memberikan pengaruh yang efektif dalam meningkatkan hasil belajar siswa kelas X SMA Negeri 1 Tambangan. 


\section{Simpulan}

Berdasarkan penelitian yang telah dilakukan, dapat disimpulkan bahwa terdapat peningkatan hasil bimbingan TIK menggunakan aplikasi E-Learning pada siswa kelas X MIA 1 SMA Negeri 1 Tambangan. Hal ini ditunjukkan oleh uji hipotesis posttest dan nilai gain ternormalisasi. Hasil uji hipotesis posttest dengan uji $t$ adalah $\mathrm{P}(0.006)<\propto(0.05)$ sehingga hipotesis penelitian diterima. Perhitungan nilai gain ternormalisasi antara kelas eksperimen juga lebih tinggi daripada kelas kontrol, yaitu nilai gain ternormalisasi kelas eksperimen $g=$ 0.54 dan pada kelas kontrol $g=0.30$. Hasil ini menunjukkan bahwa penerapan E-Learning di kelas eksperimen lebih efektif daripada penerapan media pembelajaran konvensional di kelas kontrol. Selain itu, rata-rata nilai hasil belajar siswa pun meningkat dari 67.03 pada pretest menjadi 86.09 pada posttest. Paparan di atas membuktikan bahwa penggunaan E-Learning dalam pembelajaran dapat meningkatkan hasil belajar TIK siswa di kelas X MIA 1 SMA Negeri 1 Tambangan.

Melihat hasil yang diperoleh dari penelitian ini, seharusnya sekolah yang telah memiliki E-Learning menggunakan dan mengoptimalkan keberadaan E-Learning tersebut untuk meningkatkan hasil belajar siswa. Selain itu, sebaiknya sekolah menggunakan media pembelajaran E-Learning pada mata pelajaran yang lain dengan karakteristik sesuai dengan mata pelajaran TIK yang mana sudah diujicobakan dan menghasilkan kesimpulan bahwa media pembelajaran E-Learning efektif untuk meningkatkan hasil belajar siswa.

\section{Referensi}

A. H. Suyanto, Mengenal E-Learning, Universitas Gadjah Mada, http://www.asep-hs.web.ugm.ac.id, 2005.

A. Marsidi, Profesi Keguruan Pendidikan Luar Biasa, Departemen Pendidikan Nasional Direktorat Jenderal Pendidikan Tinggi Direktorat Ketenagaan, Jakarta, 2007.

A. Rivai \& N. Sudjana, Media Pengajaran, Sinar Baru Algesindo, Bandung, 2001.

B. Murtiyasa, "Pemanfaatan Teknologi Informasi dan Komunikasi Untuk Meningkatkan Kualitas Pembelajaran Matematika", FKIP Universitas Muhammadiyah Surakarta, Surakarta, 2012.

Gibbs dalam: L. Sparrow, H. Sparrow, \& P. Swan, "Student centered learning: Is it possible?", dalam Flexible futures in tertiary teaching. Proceedings of the $9^{\text {th }}$ Annual Teaching Learning Forum, p.114, 2000.

K. Horton \& W. Horton, Katherine, E-Learning Tools and Technologies: A consumer guide for trainers, teachers, educators, and instructional designers Wiley Publishing, Inc., USA, 2003.

K. S. Dewi, "Efektivitas E-learning Sebagai Media Pembelajaran Mata Pelajaran TIK Kelas XI di SMA Negeri 1 Depok", skripsi S1, Program Studi Pendidikan Teknik Informatika Fakultas Teknik, Universitas Negeri Yogyakarta, Yogyakarta, 2011.

R. Syaeful, dalam: A. Suyitno, "Facebook Sebagai Media Kreatif E-Learning Untuk Distance Learning di Era Global", dalam BPU DINAMIK7 UPI, 2012.

R. Hake, Analyzing Change/Gain Scores, Tidak dipublikasikan. http://www.physics.indiana.edu/ sdi/AnalyzingChange-Gain.pdf, 1999, Diunduh 8 Oktober 2020.

Sugiyono, Metode Penelitian Pendidikan, ALFABETA, Bandung, p.148, 2012. T. Pambuditama, "Pengembangan Media Pembelajaran Berbasis E-Learning Untuk Meningkatkan Minat Siswa Terhadap Matematika (Pokok Bahasan Bangun Ruang SMA Kelas X Semester II)", skripsi S1, Fakultas Keguruan dan Ilmu Pendidikan, Universitas Muhammadiyah Surakarta, Surakarta, 2010.

S. Siahaan, dalam: E. Sutanta, Konsep dan Implementasi E-Learning, IST Akprind, Yogyakarta, 2009.

Tim Puslitjaknov, Metode Penelitian Pengembangan, Badan Penelitian dan Pengembangan Departemen Pendidikan Nasional, 2008.

M. Rosenberg, K. Moore, F. Hanfland, P. Shank, L. Young, L. Dublin, R. Watkins, \& M. Corry, "The eLearning Guild's Handbook of e-Learning Strategy", The eLearning Guild, Santa Rosa, p.2, 2007.

W. Sanjaya, Strategi Pembelajaran Berorientasi Standar Proses Pendidikan, Kencana, Jakarta, p.51, 2008.

Y. Miarso, Menyemai Benih Teknologi Pendidikan, Prenada Media, Jakarta, 2004. 